\title{
Assessing the environmental management and operational efficiency of Brazilian public ports that export soybeans
}

Daniele Moraes Electo de Paiva1

Marcos Aurélio Vasconcelos Freitas ${ }^{2}$

Maria Claudia Barbosa'

Nelio D. Pizzolato ${ }^{3}$

1 Universidade Federal do Rio de Janeiro / COPPE, Programa de Engenharia Civil, Rio de Janeiro / RJ — Brazil

2 Universidade Federal do Rio de Janeiro / COPPE, Programa de Planejamento Energético, Rio de Janeiro / RJ — Brazil

3 Pontifícia Universidade Católica do Rio de Janeiro / Departamento de Engenharia Industrial, Rio de Janeiro / RJ — Brazil

Using Data Envelopment Analysis (DEA), seven public ports in Brazil that trade soybeans had their environmental management assessed. Data regarding the management of sewage, solid waste, and of the presence of synanthropic fauna in public ports was used along with the port environmental index created by ANTAQ in the analysis. The results show that the quality of the environmental management needs to be addressed, so the efficiency of the system can be reached, and that DEA can be a useful tool.

Keywords: Data Envelopment Analysis (DEA); environmental efficiency; synanthropic.

\section{Avaliação da eficiência da gestão ambiental e eficiência operacional de portos públicos brasileiros que exportam soja}

Sete portos públicos brasileiros que movimentam soja foram avaliados quanto a sua gestão ambiental usando-se Análise por Envelopamento de Dados (DEA). Para a análise, os dados referentes ao gerenciamento de efluentes líquidos, resíduos sólidos, e presença de fauna sinantrópica nesses portos foram utilizados em conjunto com o Índice de Desempenho Ambiental da ANTAQ. Os resultados mostram que a qualidade da gestão ambiental precisa ser abordada para que o sistema seja eficiente como um todo, e para isso, DEA pode ser uma ferramenta útil.

Palavras-chave: análise por envelopamento de dados; eficiência ambiental; sinantrópica.

\section{Evaluación de la eficiencia de la gestión ambiental y eficiencia operacional de puertos públicos brasileños que exportan soja}

Se evaluaron siete puertos públicos brasileños de embarque de soja en cuanto a su gestión ambiental usando el análisis por envoltura de datos (DEA). Para el análisis, los datos referentes a la gestión de efluentes líquidos, residuos sólidos, y presencia de fauna sinantrópica en esos puertos se utilizaron en conjunto con el Índice de Desempeño Ambiental de la ANTAQ (Agencia Nacional de Transportes Acuáticos). Los resultados muestran que la calidad de la gestión ambiental debe abordarse para que el sistema sea eficiente en su totalidad, y para ello, el DEA puede ser una herramienta útil.

Palabras clave: análisis por envoltura de datos; eficiencia medioambiental; sinantrópica.

DOI: http://dx.doi.org/10.1590/0034-761220170311

Article received on August 9, 2017 and accepted on August 1, 2018.

ISSN: $1982-3134$ (c) (1)

[Original version]

This study was financed in part by the Coordenação de Aperfeiçoamento de Pessoal de Nível Superior- Brasil (CAPES) - Finance Code 001; and in part by CNPq, Conselho Nacional de Desenvolvimento Científico e Tecnológico - Brasil. 


\section{INTRODUCTION}

In recent years more environmental standards have been imposed to seaports, by governmental, non-governmental organizations, and society as well. Some countries have managed to keep investing on their ports, whereas others, like Brazil, left their port system lacking investment for alternating periods of time (Wanke, 2013).

In the midst of 1990, Brazil becomes a great producer of commodities, as soybeans, increasing production and commercialization, especially with the Asian market (IBGE, 2014; MDIC, 2015), compelling the port sector to start a modernization process (Wanke, 2013).

The Brazilian Secretariat of Ports (BSP) is the body of the Public Administration responsible for developing projects to promote improvement on the ports infrastructure, and set management goals to be accomplished within each port administration.

In 2011, the BSP launched a program called Program of Compliance of Solid Waste and Sewage Management in Brazilian Seaports (PCBS) to identify environmental aspects in 22 public seaports, and improve their environmental index.

The National Agency for Waterway Transport (ANTAQ), another public body, developed the Environmental Performance Index (EPI) that complies indicators of four categories (socio-cultural, economic-operational, physical-chemical, and biological-ecological) alongside with fourteen global indicators such as Environmental Governance, Security, Ports Operations Management, Energy Management, Cost and Benefits from Environmental Management, Environmental Agenda, Condominium Management of the Public Ports, and others (ANTAQ, 2012).

These initiatives and their results help evaluate the efficiency of the ports, enabling further improvement with the help of evaluation tools and actions.

\section{PORTS EFFICIENCY WITH DEA}

Many studies have been conducted using DEA throughout the years, to measure port efficiency, especially container ports, assessing physical infrastructure. Cullinane, Song, Ji, and Wang (2004) applied DEA-CCR and DEA-BCC and the software DEA-Solver-PRO 3.0 to evaluate the efficiency of European ports. Wiśnicki, Chybowski, and Czarnecki (2017) applied the CCR DEA model to evaluate container terminals in Europe based on the technology available for handling cargo employing a software; Wu and Goh (2010) showed the efficiency in emerging markets applying the $\mathrm{A} \& \mathrm{P}^{1}$ model besides DEA BCC and CCR models. Yuen, Zhang, and Cheung (2013) studied the efficiency of Chinese ports, taking into consideration foreign investments. Sousa, Nobre, Prata, and Mello (2013) (2013) and Wanke (2013) assessed the efficiency of Brazilian ports; Dyck (2015) assessed the efficiency of ports in Africa.

As for the environmental analysis, the empirical applicability of DEA influenced the increase of its popularity in this area of studies (Zhou, Ang, \& Poh, 2008). Chen and Jia (2016) cite three categories in which the studies are divided into, which are: the undesirable outputs as inputs for

\footnotetext{
1 "Developed by Andersen and Petersen in 1993, it is a model capable of differing relative efficiency levels of efficient DMUs" (Mauricio, 2015).
} 
processing; those the data has to be either minimized or maximized; and those that don't reflect the real production process.

Sueyoshi, Yuana and Goto (2017) showed that based on the number of publications regarding environment issues, this area has become the most popular for DEA researchers compared to the energy issues area. Mardani, Zavadskas, Streimikiene, Jusoh, and Khoshnoudi (2017) presented a study that reviewed papers, which used DEA to evaluate energy efficiency, and were published in 45 high-ranking journals between 2006 and 2015.

The attempts considered different approaches of DEA with environmental data, focusing mostly on the undesirable effects. Many studies with DEA are performed with data from China, knowing that this country has become the biggest in energy consumption, and pollution emissions in the world (Wu, Zhu, Chu, Liu, \& Liang, 2016). These authors measured the environmental performance of the transportation systems of 30 regions in China.

More recently, DEA was used in a study to help China's policy to reduce the consumption of natural resources, and how to allocate remaining supplies of natural resources. In this study, Zhu et al. (2017) used a DEA model based on natural resource utilization efficiency, input oriented, and showed that around $50 \%$ of the studied regions need to reduce their natural resource consumption, whereas the other half can maintain their consumption.

The advantage that DEA presents for environmental analyses can be impaired by the positive and negative aspects related to environmental data. According to Wu et al. (2016), DEA takes a much simpler approach, and it is able to evaluate performance very well.

This study presents an application of the classic DEA, using CCR model, based on constant returns to scale. It aims the employment of an available tool with friendly use that can help establish indexes according to an environmental management program, and, therefore on the goals of a management plan.

\section{MATERIAL AND METHODS}

This study applies the traditional CCR DEA model. When the result equals 1, the Decision Making Units (DMU) are efficient. As for results lower than 1, the DMU is not DEA efficient ( Cui \& Li, 2014). The DMUs identified as DEA efficient are efficient in a predetermined set of variables and homogeneous conditions of the DMUs taken into consideration, and are considered benchmarks for those which have not achieved 1, located out of the estimated efficient frontier, established by the efficient DMUs ( Turner, Windle \& Dresner, 2004).

The BCC DEA model evaluates efficiency considering variable returns to scale. When applied to a small group of DMUs, as in this study, the results show efficiency to a large number of DMUs because the model takes into consideration the differences in the performance of inputs (GEPROS, 2007).

In the present case study, the ports are all subjected to the public administration, following regulations that set the standards for environmental management, and are being operationally evaluated considering the export of soy. The ports are submitted the same environmental controlling parameters.

Journal of Public administration ｜ Rio de Janeiro 53(2):492-504, Mar. - Apr. 2019 


\subsection{Ports studied}

The seven ports (Port of Ilhéus, Itaqui, Santos, Imbituba, Paranaguá, Rio Grande, and São Francisco do Sul) are included in the PCBS, and traded $64,3 \%$ of the entire amount of soy traded in ports in Brazil in 2014.

\subsection{Data}

\subsubsection{Environmental data (input)}

Solid waste (SW) is the generator's responsibility, and for the most part, leased areas tend to present a better management system. Data was organized by:

i. Number of months of data collected in 2013;

ii. Environmental hazard according to NBR10004:2004²;

iii. Waste solid management plan (WSMP).

The most representative types of waste generated were identified as:

i. Recyclable II A or $\mathrm{B}^{3}$, showing some level of previous separation;

ii. General waste;

iii. Non-recyclable hazardous waste;

iv. Non-identified waste.

Box 1 and Box 2 show the parameters used to punctuate solid waste management, and their given values, knowing that the better the management associated with the parameter the lower the numerical value is.

\section{BOX 1 PARAMETERS AND VALUES ATTRIBUTED IN PUBLIC AREAS}

\begin{tabular}{cccc} 
Parameters & \multicolumn{3}{c}{ Classification with associated value } \\
Collection frequency & $\mathbf{1}$ & $\mathbf{2}$ & $\mathbf{3}$ \\
Type of waste & Recyclable & $<10$ months and & $<5$ months \\
SWMP & (Class II A and B) & General waste & Hazardous (Class I non- \\
Total & Applied in the port & Not applied & Absent
\end{tabular}

Source: Research data.

\footnotetext{
${ }^{2}$ Brazilian regulations for solid waste.

${ }^{3}$ IIA- Inert non-dangerous waste; IIB- Inert waste according to the Brazilian regulation policy NBR10004:2004.
} 


\begin{tabular}{cccc} 
Parameters & \multicolumn{3}{c}{ Classification with associated value } \\
& 1,5 & 3 & 4,5 \\
Collection frequency & $>=10$ months & $<10$ months and & $<5$ months \\
Type of waste & Recyclable & & \\
(Class II A and B) & General waste & Hazardous (Class I non-recyclable) \\
and non-identified
\end{tabular}

Source: Research data.

Used water (UW) - Following NBR 9896 (ABNT, 1993) is sewage, rain water and water with oil residues. Box 3 brings the parameters used to rate used water management, knowing that the better the management associated with the parameter, the lower the value is.

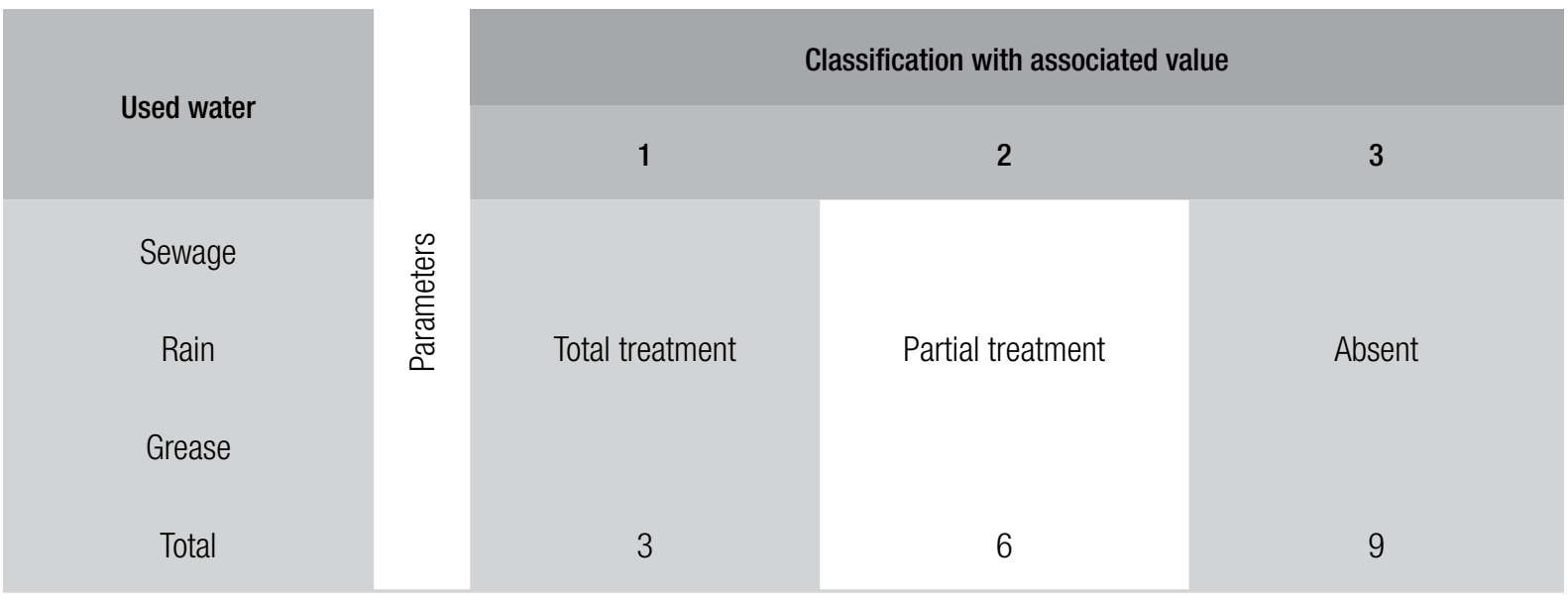

Source: Research data.

Harmful Synanthropic Species (HSS) - The parameters relate to the use of a control plan and actions taken to control the presence of rodents and doves. Box 4 brings the parameters used to rate the species management, knowing that the better the management associated with the parameter, the lower the value is. The quantification is done for the public and leased areas altogether, considering the interaction due to the mobility of these populations. 


\section{BOX 4 PARAMETERS AND VALUES ATTRIBUTED IN PUBLIC}

\begin{tabular}{lccc} 
Parameters & & Classification with associated value & $\mathbf{9}$ \\
Control plan & 3 & 6 & Absent \\
Control action & Functioning properly & Not functioning properly & Absent \\
Total & Rodents and doves & Rodents or doves & 18 \\
\hline
\end{tabular}

Source: Research data.

\subsubsection{Environmental data (output)}

Table 1 shows the values attributed to each of the seven ports, after applying the suggested methodology, and EPI for 2014.

\section{TABLE 1 VALUES ATTRIBUTED TO INPUT AND OUTPUT ENVIRONMENTAL VARIABLES}

\begin{tabular}{|c|c|c|c|c|}
\hline \multirow{3}{*}{ Ports } & \multicolumn{4}{|c|}{ Variables } \\
\hline & \multicolumn{3}{|c|}{ Input } & \multirow{2}{*}{$\begin{array}{c}\text { Output (EPI) } \\
2014\end{array}$} \\
\hline & HSS & SW & UW & \\
\hline Ilhéus & 15 & 18 & 18 & 44,22 \\
\hline Imbituba & 6 & 8,5 & 11 & 56,77 \\
\hline Itaqui & 18 & 15 & 8 & 82,26 \\
\hline Paranaguá & 9 & 11 & 13 & 81,07 \\
\hline Rio Grande & 12 & 9,5 & 14 & 70,90 \\
\hline Santos & 12 & 9 & 9 & 64,12 \\
\hline São Francisco do Sul & 12 & 8,5 & 12 & 61,97 \\
\hline
\end{tabular}

Source: Research data.

\subsubsection{Operational data (input)}

When using DEA, the most important criteria for choosing the variables is the opinion of specialists in the researched area. Experts were consulted, answering a questionnaire to identify what factors influence the most on the handling.

The experts should rank and give information about the following aspects:

- Storage capacity - If the capacity available for the port was enough, and if it allowed trade increase; 
- Parking lot - If the port had an assigned area for trucks to wait until it is time to discharge the soy;

- Available equipment for cargo handling - If it was enough, efficient for the current demand, and for a bigger demand;

- Length of berth available for the soy handling;

- Access canal depth - The need and frequency of dredging were questioned;

- Staff - Number of people needed on the handling process;

- Other issues that the operator felt were important to address, as well as the freedom to explain the choices made, and give suggestions.

Three infrastructure aspects indicated by the specialists were:

- Soybeans storage capacity (SC): It influences on the availability of merchandise to keep a regular handling flow, with trucks promptly discharging the beans;

- Depth of the port access channel (DC): It can determine if large cargo vessels cannot access the port;

- Berth length (BL): It influences on the size of the vessel able to dock on the port and the number machineries, such as ship loaders;

\subsubsection{Operational data (output)}

For the operational evaluation with DEA, two tests were conducted, each with a different output data: Volume of soybeans traded in 2014 ( $\mathrm{t} /$ year) and Productivity $(\mathrm{t} / \mathrm{h})$, which indicates the amount traded (in tons), in each terminal or group of berths, in relation to the period of time of the berths occupancy (ANTAQ, 2003).

Table 2 shows the input and output data selected for the seven ports.

\section{TABLE 2 DATA FOR THE OPERATIONAL DEA EFFICIENCY}

\begin{tabular}{|c|c|c|c|c|c|}
\hline \multirow{3}{*}{ Ports } & \multicolumn{5}{|c|}{ Variables } \\
\hline & \multicolumn{3}{|c|}{ Input } & \multicolumn{2}{|r|}{ Output } \\
\hline & $\begin{array}{l}\text { Soy storage } \\
\text { capacity }(\mathrm{t})\end{array}$ & $\begin{array}{l}\text { Depth of the port } \\
\text { access channel (m) }\end{array}$ & $\begin{array}{l}\text { Berth length } \\
\text { (m) }\end{array}$ & Productivity (t/h) & $\begin{array}{c}\text { Volume of soy traded in } \\
2014 \text { (t/year) }\end{array}$ \\
\hline Ilhéus & 50.000 & 8,20 & 216 & 94 & $172.852,00$ \\
\hline Imbituba & 40.000 & 10,80 & 245 & 172 & $513.574,00$ \\
\hline Itaqui & 216.000 & 23 & 280 & 853 & $3.054 .084,00$ \\
\hline Paranaguá & 1.255 .500 & 15 & 961 & 763 & 7.306.643,00 \\
\hline Rio Grande & 1.583 .000 & 14,50 & 1362 & 533 & $4.751 .563,00$ \\
\hline Santos & 998.000 & 13,20 & 1478 & 703 & $11.123 .777,00$ \\
\hline São Francisco do Sul & 369.000 & 12 & 220 & 1.080 & $4.323 .843,00$ \\
\hline
\end{tabular}

Source: SIG/ANTAQ (2015); CODESP (2012); LABTRANS (2013, 2012). 


\section{RESULTS AND DISCUSSION}

The software EMS - Efficiency Measurement System was employed to solve DEA.

The BCC model considers variable return to scale, and it is more likely to identify a higher number of efficient units. A test with the BCC model was conducted, and six ports were identified as efficient, which for the purpose of this study, would not help significantly.

The CCR model uses constant returns to scale and is more appropriated, as the results that follow show. The number of efficient units is small, allowing the use of these as references, or benchmarks for the inefficient ones to improve.

\subsection{Environmental DEA efficiency}

Applying the CCR DEA model (also known as CRS- Constant Return to Scale) with input orientation, the emphasis is to decrease the input data, keeping the output data constant, in order to achieve an efficiency frontier.

The following table brings the results obtained by the Efficiency Measurement System (EMS) software, showing that the DMUs (Decision Making Units) with relative efficiency were DMU 2 and 7, both scoring $100 \%(\mathrm{DEA}=1)$. They are efficient, given the conditions of all of the ports analyzed, in relation to the others.

\section{TABLE 3 DEA ENVIRONMENTAL EFFICIENCY}

\begin{tabular}{|c|c|c|c|c|c|c|c|}
\hline DMU & Ports & Score & HSS & SW & UW & EPI & Benchmarks \\
\hline 1 & ILH & $32,99 \%$ & 0,38 & 0,31 & 0,31 & 1,00 & $2(0,10) 7(0,43)$ \\
\hline 2 & IMB & $100,00 \%$ & 0,39 & 0,37 & 0,24 & 1,00 & 3 \\
\hline 3 & ITA & $86,68 \%$ & 0,26 & 0,36 & 0,38 & 1,00 & $7(0,96)$ \\
\hline 4 & PN & $81,42 \%$ & 0,36 & 0,29 & 0,35 & 1,00 & $2(0,62) 7(0,35)$ \\
\hline 5 & $R G$ & $88,18 \%$ & 0,44 & 0,32 & 0,24 & 1,00 & $2(0,31) 7(0,72)$ \\
\hline 6 & SAN & $92,15 \%$ & 0,21 & 0,26 & 0,53 & 1,00 & $7(0,84)$ \\
\hline 7 & SFS & $100,00 \%$ & 0,28 & 0,33 & 0,40 & 1,00 & 5 \\
\hline
\end{tabular}

Source: Results obtained by applying DEA to the research data.

The Benchmarks column shows the DMUs with DEA efficiency that can be considered benchmarks for the DEA inefficient DMUs. In brackets, the corresponding intensities, the "lambdas" indicate the intensity of correspondence between the DMU inefficient and a DMU benchmark. DMU 2 is a benchmark for 3 ports, while DMU 7 is a benchmark for 5 ports.

DMU 2 was strongly influenced by the input data, especially by the management of HSS. DMU 2 has the best management program showing total absence of harmful fauna in the port area. The 
practices of DMU 2 can be used as a reference guide for DMUs 1, 4 and 5, with further consideration as how to adjust these practices to the actual port that is in need of improvement.

DMU 7 efficiency was influenced by its high value assigned to EPI. DMU 4 has both efficient ports as benchmarks, and the values 0,62 and 0,35 show that DMU 2 is a more "recommended" benchmark, than DMU 7 is.

\subsection{Operational DEA efficiency}

\subsubsection{Efficiency with quantity of soybeans traded}

Table 4 brings results for DEA analysis, which showed that two DMUs were considered DEA efficient. DMU 3 and 6 were equally considered as benchmarks for 3 ports, each.

TABLE 4 DEA OPERATIONAL EFFICIENCY WITH VOLUME TRADED

\begin{tabular}{|c|c|c|c|c|c|c|}
\hline DMU & Ports & Score & SC & $\mathrm{DC}$ & TON & Benchmarks \\
\hline 1 & ILH & $18,31 \%$ & 0,87 & 0,13 & 1,00 & $3(0,06)$ \\
\hline 2 & $\mathrm{IMB}$ & $62,75 \%$ & 0,80 & 0,20 & 1,00 & $3(0,17)$ \\
\hline 3 & ITA & $100,00 \%$ & 0,89 & 0,11 & 1,00 & 3 \\
\hline 4 & PN & $53,81 \%$ & 0,72 & 0,28 & 1,00 & $6(0,66)$ \\
\hline 5 & $R G$ & $29,73 \%$ & 0,77 & 0,23 & 1,00 & $6(0,43)$ \\
\hline 6 & SAN & $100,00 \%$ & 0,69 & 0,31 & 1,00 & 3 \\
\hline 7 & SFS & $95,48 \%$ & 0,85 & 0,15 & 1,00 & $\begin{array}{l}3(0,33) \\
6(0,30)\end{array}$ \\
\hline
\end{tabular}

Source: Results obtained by applying DEA to the research data.

DMU 7 had the best result amongst the non-efficient ones, and there was great disparity in the results found with DEA as shown in Table 4. DMU 1 was, once more, the one with the lowest efficiency with a 0.18 DEA score, showing that this port needs great improvement in both areas. DMU 2, with a DEA score $=1$ on the environmental analysis, had a DEA score $=0,63$ on the operational analysis, what can possibly be exxplained by its recent insertion on the trade market of soy. Port of Imbituba started operating the product in 2014 , and has a low storage capacity.

DMUs 4 and 5 have the biggest storage capacity, and are the second and third highest in volume traded in 2014 (see Table 2), and the results show that their storage capacity is being underused, and the ports can either work to increase the volume traded, or increase the use of the storage. 
RAP Assessing the environmental management and operational efficiency of Brazilian public ports that export soybeans

\subsubsection{Efficiency with productivity}

Table 5 shows the results from DEA, with two efficient DMUs (DMU 3 and DMU 7).

TABLE 5 DEA OPERATIONAL EFFICIENCY WITH PRODUCTIVITY

\begin{tabular}{ccccccc} 
DMU & Ports & Score & SC & BL & P & \multicolumn{1}{c}{ Benchmarks } \\
\hline 1 & ILH & $20,78 \%$ & 0,29 & 0,71 & 1,00 & $3(0,11)$ \\
\hline 2 & IMB & $36,70 \%$ & 0,23 & 0,77 & 1,00 & $3(0,20)$ \\
3 & ITA & $100,00 \%$ & 0,51 & 0,49 & 1,00 & 5 \\
\hline 4 & PN & $18,57 \%$ & 0,52 & 0,48 & 1,00 & $3(0,22) 7(0,54)$ \\
5 & RG & $9,72 \%$ & 0,49 & 0,51 & 1,00 & $3(0,22) 7(0,32)$ \\
6 & SAN & $14,89 \%$ & 0,36 & 0,64 & 1,00 & $3(0,72) 7(0,08)$ \\
7 & SFS & $100,00 \%$ & 0,14 & 0,86 & 1,00 & 3
\end{tabular}

Source: Research data.

DMU 3 represents a benchmark for other 5 DMUs. For DMU 7, the result may be influenced by its high productivity, and the BL DEA result can indicate a good usage of its capacity. Short berth lengths imply on less machinery available along the berths, and high productivity on these short berths, shows efficient use of the resources.

DMU 6 accounts $1.478 \mathrm{~m}$ of BL, while DMU 5 has $1362 \mathrm{~m}$, and DMU 4, $961 \mathrm{~m}$. These ports have the greatest availability of berths amongst the group, and although they have potential to be efficient, this indicates inefficiency managing the space and equipment available.

DMU 2 had a lower score in this analysis in comparison to the previous one, which can be related to a lack of proper structures in the port to support the service, like conveyors or ship loaders. It is possible to confirm that the BL had a heavier impact on the efficiency of this DMU ( $77 \% \mathrm{BL})$, as it measures $245 \mathrm{~m}$, and is one of the shortest in the group. This shows that the berth is being used to a high rate, while the storage units need to be better managed.

\section{CONCLUSIONS}

The CCR model is a tool that helps on the indication of what inputs must decrease, keeping the level of outputs, in order to improve the efficiency of the DMU observed. The basics of the model applied to a set of numerical data, previously codified, can produce results of efficiency that need support for interpretation, based on the codification system adopted.

This study determined the environmental efficiency of seven ports that trade soybeans, using a codification system of managerial data involving three environmental aspects which are not commonly assessed with DEA, but of great importance to the evaluation of the environment management in 
Brazilian Ports. Decreasing the inputs, according to the input orientation, meant identifying the best environment management system, which can be suggested as models to the inefficient units.

Other two analysis were conducted, this time for the operational infrastructure, which showed great disparity of results in each analysis, and between them. The results of the environmental analysis, once confronted with the operational ones show that most ports presented environmental efficiency near the efficiency frontier that was set by two DMUs, while on the operational efficiency analysis big differences were shown, caused by the inequality of the data. In terms of application of the results, DMUs placed not so near the efficiency frontier can benefit more, once their weaknesses are identified, and the management tools used by their benchmarks can be researched and applied to them as a source of improvement.

Inequalities in the variables may be good, once DMUs can score far from the efficiency frontier. It is suggested that, for the environmental analysis, more criteria are used to refine the values, and therefore, the codification can generate values farther apart, and by doing so, longer distances between the efficient DMU and the others, which is desirable when using DEA. Refining the variables, in this application, means creating more management tools that can set the values apart.

It was shown that ports with a great volume of soybeans traded in 2014 were not environmentally efficient, except for the port of Santos that presented a result near the efficiency frontier, and was efficient when the volume of soybeans traded was the output data, but failed on its level of efficiency when the productivity was taken into the analysis. The operational DEA analysis showed that, from a managerial point of view, the ports need to improve their system all year around, making a better use of the infrastructure installed, which currently presents conservation and operation problems, also contributing to environmental problems, related mainly to sanitation.

These results can be useful to the Government and, therefore, the Public Administration, once programs or regulations are thought out, aiming to control levels of pollution, applying established parameters of efficiency as a tool. It is necessary that the Public Administration creates indexes that can be measured and evaluated from time to time, allowing the ports to improve their levels of environmental efficiency, with further understanding of where to allocate efforts for improvement. 


\section{REFERENCES}

Agência Nacional de Transportes Aquaviários. (2003). Indicadores de Desempenho Portuário. Brasília, DF: Autor.

Agência Nacional de Transportes Aquaviários. (2012). Índice de Desempenho Ambiental - IDA para Instalações Portuárias. Brasília, DF: Autor.

Agência Nacional de Transportes Aquaviários. (2014). O Índice de Desempenho Ambiental - IDA. Brasília, DF: Autor. Retrieved from http://web.antaq. gov.br/Portal/MeioAmbiente_IDA.asp

Agência Nacional de Transportes Aquaviários. (2015). SIGANTAQ Sistema de Informações Gerenciais. Brasília, DF: Autor. Retrieved from http://www.antaq. gov.br/sistemas/sig/InformacaoResultadoAvancado. asp

Associação Brasileira de Normas Técnicas. (2004). NBR 9896: Glossário de poluição das águas. Rio de Janeiro: Autor.

Chen, L., \& Jia, G. (2017). Environmental efficiency analysis of China's regional industry: a data envelopment analysis (DEA) based approach. Journal of Cleaner Production, 142(2), 846-853.

Companhia das Docas de São Paulo. (2012). Plano de Desenvolvimento e Zoneamento do Porto de Santos 2012-2024. Santos, SP: Autor.

Cullinane, K., Song, D. W., Ji, P., \& Wang, T. F. (2004). An Application of DEA Windows Analysis to Container Port Production Efficiency. Review of Network Economics, 3(2), 184-206.

Instituto Brasileiro de Geografia e Estatística. (2014). IBGE confirma safra recorde em 2013 eprevê produção ainda maior em 2014. Rio de Janeiro: Autor. Retrieved from http://saladeimprensa.ibge.gov.br/noticias? view $=$ noticia\&id $=1$ \&busca $=1$ \&idnoticia $=2561$

Mardania, A., Zavadskas, E. K., Streimikiene, D., Jusoh, A., \& Khoshnoudi, M. (2017, abril). A comprehensive review of data envelopment analysis (DEA) approach in energy efficiency. Renewable and Sustainable Energy Reviews, 70, 1298-1322.

Mauricio, M. P. G. (2015). Aduana e seus indicadores de desempenho: avaliação comparativa da eficiência das regiões fiscais do Brasil pela Análise Envoltória de Dados (Dissertação de Mestrado). Universidade Estadual de Campinas, Campinas, SP.
Ministério do Desenvolvimento Indústria e Comércio. (2014). Balança Comercial Brasileira Dados Consolidados 2014. Retrieved from http:// www.mdic.gov.br/arquivos/dwnl_1423144482.pdf

Sousa, J. N. C. de, Jr., Nobre, E. F., Jr., Prata, B. de A., \& Mello, J. C. C. B. S. de. (2013). Avaliação da eficiência dos portos utilizando análise envoltória de dados: estudo de caso dos portos da região nordeste do Brasil. Journal of Transport Literature, 7(4), 75-106.

Sueyoshi, T., Yuana, Y., \& Goto, M. (2017, fevereiro). A literature study for DEA applied to energy and environment. Energy Economics, 62, 104-124.

Turner, H., Windle, R., \& Dresner, M. (2004). North American Containerport: 1984-1997. Transportation Research Part E, 40(4), 339-356.

Van Dyck, G. K. (2015). Assessment of Port Efficiency in West Africa Using Data Envelopment Analysis. American Journal of Industrial and Business Management, 5(4), 208-218.

Wanke, P. F. (2013). Physical Infrastructure and Shipment Consolidation Efficiency Drivers in Brazilian Ports: A Two-stage Network-DEA Approach. Transport Policy, 29, 145-153.

Wiśnicki, B., Chybowski, L., \& Czarnecki, M. (2017). Analysis of the efficiency of port container terminals with the use of the data envelopment analysis method of relative productivity evaluation. Management Systems in Production Engineering, 1(25), 9-15.

Wu, Y.-C. J., \& Goh, M. (2010). Container port efficiency in emerging and more advanced markets. Transportation Research Part E: Logistics and Transportation Review, 46(6), 1030-1042

Wu, J., Zhu, Q., Chu, J., Liu, H., \& Liang, L. (2016). Measuring energy and environmental efficiency of transportation systems in China based on a parallel DEA approach. Transportation Research Part D, 48, 460-472.

Yuen, A. C., Zhang, A., \& Cheung, W. (2013). Foreign participation and competition: A way to improve the container port efficiency in China? Transportation Research Part A: Policy and Practice, 49, 220-231. 
Zhou, P., Ang, B. W., \& Poh, K. L. (2018). Measuring environmental performance under different environmental DEA technologies. Energy Economics, 30(1), 1-14.
Zhu, Q., Wu, J., Li, X., \& Xiong, B. (2017). China’s regional natural resource allocation and utilization: A DEA-based approach in a big data environment. Journal of Cleaner Production, 142(2), 809-818.

\section{Daniele Moraes Electo de Paiva}

https://orcid.org/0000-0002-5925-2283

Master in Civil Engineering. Student granted by CNPq - Brasil. E-mail: daniele.paiva@ivig.coppe.ufrj.br

\section{Marcos Aurélio Vasconcelos Freitas}

https://orcid.org/0000-0002-9242-1288

Doctor in Economie de l'Environnement and adjunct professor of the Energy Planning Program of Universidade Federal do Rio de Janeiro. E-mail: mfreitas@ppe.ufrj.br

\section{Maria Claudia Barbosa}

https://orcid.org/0000-0002-7695-7779

$\mathrm{PhD}$ in Civil Engineering and associate professor of the Civil Engineering Program of Universidade Federal do Rio de Janeiro. E-mail: mclaudia@coc.ufrj.br

\section{Nélio D. Pizzolato}

https://orcid.org/0000-0002-1558-8914

$\mathrm{PhD}$ in Business and Associate Professor of the Industrial Engineering Department of Pontifícia Universidade Católica do Rio de Janeiro. E-mail: ndp@puc-rio.br 